\title{
The Uneasy Gaze - Appearing for Interviews to get Married - An Empirical Investigation into the Pre-marital Arranged Marriage Negotiations in Urban Kolkata
}

\author{
Sucharita Sen \\ PhD Scholar, Victoria University of Wellington, New Zealand. \\ Email:sucharitasen13@gmail.com
}

\begin{abstract}
Indian society, when viewed from a Foucauldian feminist perspective offers a curious and unique example of societal scrutiny over its members. This overt exercise of power influences individual behaviour, attitudes and has a profound influence on decision making. In this context, this paper argues, within an empirical framework, the limitations of freedom of choice for women in pre-marital arranged marriage negotiations. Women find themselves coercively thrust into uneasy situations of objectification, forced to mould themselves to fit into hegemonic patriarchal parameters. They are lambasted if they fail to fulfil the required expectations. Based on a survey of 250 young brides and prospective brides of upper-caste, middle class background in urban Kolkata, I argue that the pre-marital negotiations in arranged marriages systematically subjugate the women. Faced with societal and familial pressure, the women often find themselves marginalised and subjugated in the process of arranged marriage.
\end{abstract}

Keywords: Women, Patriarchy, Arranged Marriages, Objectification.

On a rainy Sunday evening, Suhasini stood silently at the receiving end of her mother's wrath for returning home late. She had gone to her neighbour's residence to bring a book that would aid her preparation in her final examinations of her undergraduate degree. It was not particularly because she had been out in the rains, amidst the foul weather, that she was presently being reprimanded. This Sunday was not just another day as it usually was for other weeks. The Sunday was special. After a few unsuccessful attempts at getting Suhasini married, her aunt had generously brokered another marriage proposal for her. The family of the prospective groom had scheduled a visit to Suhasini's flat in South Kolkata that Sunday. Anirban, the groom too would be coming. After a prolonged fifteen-minute argument with her mother, she found herself being locked in her room, with a saree in front her and some of her mother's ancestral jewellery. It was her mother's strict instruction that Suhasini wears a saree when Anirban and his family visited. Helplessly, she got herself decked up to face her in-laws. Patiently, she sat in her room. By the time the groom's family arrived, she had been briefed on the appropriate behaviour that she should exhibit in front of her in-laws. Her mother instructed, 'Answer properly all the questions that they ask you'. Suhasini wondered how her upcoming interview would be and which of the interview board members sitting in her drawing room would be impressed by her answers. As Suhasini sat down in front of her prospective in-laws, Anirban and his parents continued to stare at her. Anirban's mother whispered something to her husband and he silently laughed. Suhasini's mother broke the awkward silence to

(C) AesthetixMS 2021. This Open Access article is published under a Creative Commons Attribution Non-Commercial 4.0 International License (http://creativecommons.org/licenses/by-nc/4.o/), which permits non-commercial re-use, distribution, and reproduction in any medium, provided the original work is properly cited. For citation use the DOI. For commercial re-use, please contact editor@rupkatha.com. 
give an impressive list of her daughter's abilities. 'She can cook well, in fact, she can cook for a large number of people. In last year's Durga Puja, she had cooked the bhog. She can sing too. If you want, she can sing a song for you now. She is quite adept in household chores. You see, she will be a very obedient daughter in-law'. Suhasini wondered to which post she was applying, a maid or a cook or a singer. As Anirban continued to stare at her, Suhasini got up and left the nauseating atmosphere.

In India, arranged marriages follow a similar pattern. The groom along with some of his family members visit the bride's house to 'see' the bride. This concept of coming to see the bride occupied a significant and often the most important part of the marriage negotiations. The girl is made to dress up in a traditional attire and sit in front of the groom and his family. The girl is then asked a number of questions, through which the groom's family judges her suitability in becoming a member of the new household. This transformed often into a hilarious enterprise. Suhasini, for example, felt that she was appearing for a job interview. The groom's family, in most cases, follow a pattern of questioning, mainly based on the girl's qualities, her willingness to adjust in a new home and whether she can commit herself to look after the household. What emerges is the overwhelming expectations from the bride to fulfil certain desired parameters. Not much is asked from the boy, who is rather treated by the girl's family as a revered guest.

Parents and families actively participate in choosing a person's marital partner and 'arranging' his or her marriage (Jacobson, 1996; Batabyal, 2001; Singh, 2005; Chawla, 2007; Madathil \& Benshoff, 2008; Bowman and Dollahite, 2013). Consequently, the girl and the boy have less opinions in such marriage negotiations. There is no dearth in an analytical literature on marriages in India. In India, around ninety percent of marriages are arranged (Batabyal, 2001; Myers et al., 2005; Singh, 2005; Alexander et.al, 2006; Chawla, 2007; Madathil \& Benshoff, 2008). Despite the widespread dissemination of Western ideals of individualism, the spread of nuclear family, economic independence of women, the majority of Indians prefer an arranged marriage with parental consent (Batabyal, 2001; Natrajan \& Thomas, 2002; Singh, 2005; Derne, 2005; Alexander et al., 2006; Chawla, 2007;). Such findings have been corroborated by research which surveyed unmarried youth, inquiring into their opinions on the process of arranged marriage and parental involvement (Sprecher \& Chandak, 1992; Chowdhury and Travato, 1994; De Silva, 2005; Ghimire et al., 2006; Medora, 2003). On the basis of such studies, it has been argued that the youth continue to prefer arranged marriages. However, they are becoming increasingly involved in marriage decisions and spouse selection, exerting a certain amount of say and choice in the selection of their prospective partners. In this context, Tuxen (2013) argues that in India, there has also emerged increasing instances of 'arranged love marriage'. In this, although the bride and the groom might have chosen their partners, a marriage is settled only after parental consent and a negotiation among the two families, thus making it appear like a traditional arranged marriage. For the purpose of this paper, I use the term arranged marriage to mean marriages where the bride and the groom are unknown to each other and the marital negotiations are completely undertaken by the respective families.

Alexander et al. (2006) argues that arranged marriages in India enjoy a high rate of persistence, with negligible instances of dissolution or divorce. The rate of dissolution of the marriage bond, the sanctity of which is maintained by religious sanctions had correspondingly been low (Yelsma \& Athappilly, 1988; Batabyal, 2001; Singh, 2005; Chawla, 2007; Madathil \& Benshoff, 2008; Sandhya, 2009). However, Chacko (2003) and Medora (2007) argued that there was a significant level of dissatisfaction in arranged marriages and dowry deaths, wife beatings, domestic violence and abusive relationships were on the increase in such marriages. This contradiction in literature, argued Binu Edathumparambil (2017), necessitated an analysis of the lived experiences 
of the couples in arranged marriages. Consequently, he conducted a detailed research on the quality of relationships and the quality of alternatives for couples in arranged marriages. Based on the Investment model, Concurrent Triangulation Design and the Triangular theory of love, Edathumparambil, on the basis of a comparative qualitative-quantitative analysis concluded that in arranged marriages, the quality of satisfaction in relationships was considerably high. But the quality of alternatives for people living in such marriages was conspicuously low. The reason could be attributed to the overwhelming hegemony of arranged marriages as an indissoluble contract (Chandrasekhar, 1954; Derné, 2000; Medora, 2003; Sonpar, 2005). Any deviation from this would bring disgrace on the married couple, particularly the women, and subject them to social ostracization.

In all these studies, there has been an overarching emphasis on the marital life of the couples, their happiness and problems. Tulika Jaiswal (2014) argues that arranged marriages in India are in a state of transition. While there is a move towards the more westernised notions of choice and freedom in selecting prospective partners for themselves, familial involvement has not been completely eroded. She argues that young and educated males have a likelihood of increased participation in spouse selection, freedom of choice and decision making in the negotiations during an arranged marriage. In this context, I argue that while the men do exercise a certain amount of choice, the women's choice are not just comparatively limited, as Jaiswal (2014) argues, but the process of an arranged marriage, in terms of the pre-marital negotiations lead to a rampant objectification of women. This paper particularly seeks to build up on Jaiswal's analysis, contributing to the existing literature, an empirical analysis of the lived experiences, in terms of gender disparities, of prospective brides in urban Kolkata. In this paper, I argue that pre-marriage negotiations in arranged marriages create humiliating and demeaning conditions for the women in her natal family itself. For this, I conducted a survey among the urban educated middle class, upper caste Hindu Bengali brides in the city of Kolkata. The modern family in urban Kolkata is structurally nuclear but functionally joint. In this context I divide the independent variables of my survey into external and internal factors. All these factors create the less-than-optimal conditions for women of marriageable age. The internal factors include patriarchal traditions in determining marriage, the higher status ascribed to the groom and his family, the stereotypical age-group within which women needs to get married and the active involvement of extended family members in the event of arranged marriages. Other factors like the societal surveillance, particularly the neighbourhood's gaze over unmarried women, instances of girls of a similar age getting married are factors which acts as an external influence on the parents. 
Figure 1 - Conceptual Framework

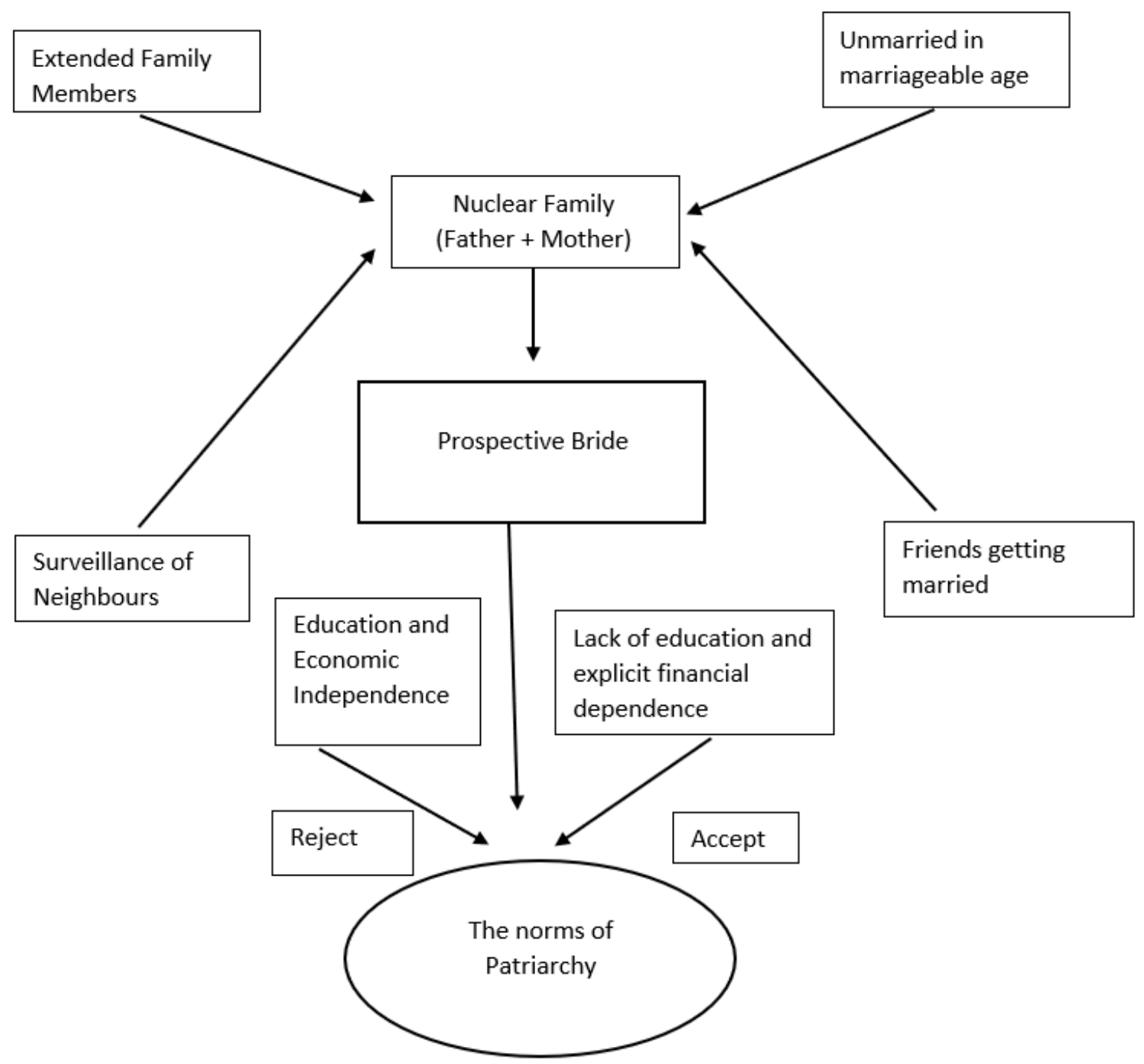

\section{Research Methodology and Theoretical Framework}

The study was conducted within an empirical framework. The participants were selected by the methods of purposive sampling and snowball sampling. Face-to-face interviews were conducted. The interview consisted of a structured questionnaire. The questionnaire had both close-ended questions (mainly formulated and presented in the Likert scale) and open-ended questionnaires. The combination of both types facilitated a qualitative and quantitate analysis.

Figure 2 - Research Sample Size

\begin{tabular}{|c|c|c|c|}
\hline Sample Size & \multicolumn{3}{|c|}{ Sample Demographics } \\
\hline & Brahmins & Kayasthas & Baidyas \\
\hline 250 & 100 & 80 & 70 \\
\hline
\end{tabular}


The analysis was conducted from a Foucauldian feminist perspective. Foucault (1978) argued that family served both as an institution of sovereign and disciplinary power. In Disciplining the Family (1997) and Family Bonds - Genealogies of Race and Gender (2007), Ellen K. Feder argues, from a Foucauldian feminist perspective, for ways in which disciplinary power is exercised inside the family. Children are aware that they are under the constant surveillance and supervision of their parents. Parents also are conscious of the surveillance by the society in general and their neighbours in particular (Feder, 2007, pp. 15, 41). Thus, children conform to the expectations and wishes of their parents, and parents to the gazes of their neighbours, as well as to those of 'teachers, doctors, classmates, and the parents of classmates, whom they monitor in turn'. Thus, the authority of the family over its members is more intimate, irreplaceable and deemed vital in an individual's life (Sen, 2020).

This two-tiered surveillance, I argue is exercised within the norms and injunctions of patriarchy. Thus, patriarchy assumes a structural, functional and institutional dimension. In its structural form, it is manifested in the in the structure of family system and patrilocal residence. In its functional dimension, it is manifested in the way the daily lives are woven in a society, including rituals, customs, marriage preferences, age of marriage and social stigma for spinsters. In its institutional aspect, the family (Sen, 2005) and neighbourhood become the epitome of patriarchy. In this context, the negotiations in an arranged marriage reflects absence of coercion, i.e., parents do not impose their decisions or judgements on their children. However, the hegemonic factors of the suitable marriageable age and similar patriarchal notions, as this paper will show, exercises a constraint on the bride. The bride, though unwillingly, accepts these injunctions, falling in line with the patriarchal dictates.

Figure 3 - Scheme of Analysis

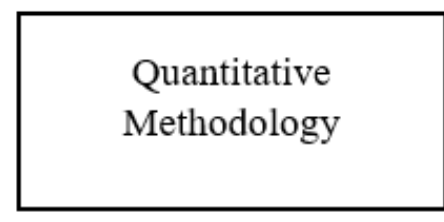

Qualitative

Methodology

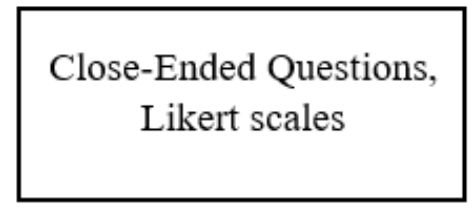

Open-Ended questions, Unstructured questions

Analysis

Analysis 
6 | Rupkatha Journal, Vol. 13, No. 2, 2021

\section{Hegemonic Hurdles, Patriarchal Parameters, Limitations of Choice and Social Scrutiny - Analysing the Survey Results}

The pivotal religious Hindu legal text known as Manusmriti lays down the significance of marriage and the duties of a husband and wife (Doniger \& Smith, 1991). The role of the husband includes providing, caring for and protecting the wife, and the role of the wife is to be devoted to the husband, maintain her chastity and to look after his children (Jaiswal, 2014). In the Hindu religion, marriage is perceived to be a stepping stone for girls and boys in becoming adults and starting families. This cultural emphasis on marriage adds social and religious pressure for both young men and young women to get married (Jaiswal, 2014). For a, marriage is considered indispensable, because without a wife or a husband, they cannot enter the Grihastha ashrama (the life stage of a householder) and is thus forbidden to have an offspring (Jaiswal, 2014).

The modernization of the institution of marriage in India has led to the emergence of three distinct and discernible patterns of arranged marriage - the traditional, modified traditional and cooperative traditional patterns (Stopes-Roe \& Cochrane, 1990). Jaiswal (2014) observed that the common feature that runs through all the three patterns of marriage is that the parents are the decision makers. The difference lies only in the degree of participation and the right to veto which is provided to the marrying individual (Jaiswal, 2014). Traditional arranged marriages are those in which there is an absence of any participation from the marrying individual, he or she has no right to veto the partner choice, and the couple does not meet until the wedding day (Jaiswal, 2014). In the modified traditional arranged marriage pattern, the marrying individual's inputs are considered during the selection of partners and the couple formally meets before marriage, but the individual has very limited freedom to veto the choice of partner. In the cooperative traditional pattern, the marrying individual makes the selection along with the family, meets the prospective spouse before the marriage and has the right to refuse or accept the proposal (Jaiswal, 2014). There is an increasing movement towards the cooperative traditional pattern amongst younger generations, and there can also be discerned a slight increase in number of inter-caste and inter-religious marriages (Corwin, 1977; Pasupathi, 2002; Fuller \& Narasimhan, 2008; Grover, 2009; Jaiswal, 2014). As the survey results will show, although the cooperative traditional pattern may be on the increase, the process of negotiations smack of patriarchal bias and continue to follow the traditional patterns. In this sense, the modernisation of marriage has been a modernisation for the groom or the boy. The girl or the prospective bride continues to enjoy a low freedom of choice, often finding herself too objectified and belittled in the wake of the marriage negotiations.

The responsibilities ascribed to the husband and the wife in the ancient lawbook of Manu laid down the patriarchal framework of the Indian marriage system. Consequentially, prospective brides in the negotiations before an arranged marriage continue to be subjected to profound uneasiness. Sanchita, a young girl of twenty-nine, expressed this uneasiness of having being made to appear before families of prospective grooms. Sanchita had internalised the fact that being darkskinned like her, was an inevitable impediment in the process of finding a suitable groom. I know how difficult it will be for me to find a groom. Every weekend, a family comes to see me. They ask me if I can cook, if I can do household work. But they all go away unsatisfied. Last week, too a family came. They have not yet contacted us. I don't think they will, observed Sanchita.

I do not go to family gatherings. I do not go out in the neighbourhood too. It seems as if everyone has a singular question to ask, 'When will you get married?' lamented Archishama, aged thirty. Archishama and Sanchita had similar experiences with meagre variations. Sanchita's conviction that being dark-skinnned is a significant barrier in finding a prospective groom reveals the stereotyped gender roles attributed to a girl. While there is no emphasis on the skin colour on 
the boy and less on his qualities, the girl is subjected to a thorough examination by the groom's parents regarding her eligibility to become a potential daughter-in-law.

Nivedita jokingly remarked that it seems we are providing free Sunday snacks. Every Sunday, we have visitors who come to see me. They arrive, stay for an hour and leave, never to return or contact again. I feel it is better to remain unmarried now. But my relatives will not spare me. Every week, my aunt brings a new proposal. My mother and father dreams of getting me married and I have to dress up and put up with this resurgence of drama every Sunday. Nivedita's sarcasm reflects the unideal circumstances which form a part of these women's lived experiences. Inability to find a suitable groom raised eyebrows and exposed the girl's family to innumerable questions from family members and the neighbours.

Rupanjana narrated her experience of arranged marriage negotiations. Every time a family would come to see me, my mother would caution me, 'Please answer them properly. If you do not get married, what will our neighbours say? All the girls of your age in this neighbourhood have got married. We must marry you off now.' Rupanjana was utterly frustrated and disillusioned, not at the linear progression of rejections that came, but with the mounting pressure on her to get married. The groom's families never gave any reason for their rejection. But it just increased the anxiety of my parents, lamented Rupanjana. Thus, the societal structure plays an important role in disciplining the female according to patriarchal norms.

The respondents had little choice in selecting their prospective partners. Rather series of rejections and inability to get married, drew some to desperation, while others declined to get married. Sudeshna recounted how her prospective groom wanted to know if she had a boyfriend in her college life, the only place time when she had been to a coeducational institution. Disgusted, Sudeshna refused to answer any further questions from either the prospective groom or his family, only to be lambasted later by her parents for being too headstrong. I did not want to know if the prospective groom had a girlfriend. Why this stereotype? Two previous negotiations had failed because I had honestly confessed to having broken up with my boyfriend, said Sudeshna.

Toshali's story was a little different from Sudeshna, Rupanjana and Nivedita. Toshali had been brought up in a conservative family and had travelled to Delhi to pursue her postgraduate studies. Her extended family members had warned her parents against sending their daughter to Delhi. They thought that I would get derailed and I will be spoilt, said Toshali. They had nearly convinced my parents, but I managed to slip out after I assured my parents that I will only focus on my studies. So off went Toshali to pursue her dreams. Being a studious girl, she soon made a mark at Delhi University. She excelled in studies and also gained fame and reputation for her cocurricular activities. Despite a lot of advances from boys, she never got herself into a relationship. After her degree, she secured a job in a private company in Noida, which had a branch in Kolkata. Soon, she returned to Kolkata, to find out that her family members were trying to persuade her parents to get her married. Her cousins been married, and she was the last in the queue. Thus, pressure started mounting. As marriage negotiations opened up, Toshali's frustration set in. I felt like a caged animal in a zoo. Every time a family would come to see me, I would be facing a number of questions. They have lots of questions on my lifestyle, my days in Delhi and whether I can secure a work-life balance in my married life. Questions also speculated about whether I may contemplate resigning from job after my marriage to look after the household. Toshali however did not give in to these pressures. She fought back and refused to yield. It catapulted her family members to denounce her of having being spoilt by her exposure in Delhi and her job. Toshali, however, continued her job and is still waiting for a suitable boy. 
Patriarchal parameters reign rampant in negotiations preceding arranged marriages. Testimonies reveal that the girls are prepared to appear in front of the groom's family. Adequate care is taken to make her look presentable. Often, for experienced girls, who have undergone series of rejections are made to rehearse the answers which are likely to impress the groom's family. Gitanjali recounted her nightmarish Saturday evenings when she was groomed by her mother and her aunt as she would get dressed to meet her prospective in-laws. The grooming centred around how to walk, how to sit and what to answer to the groom's family and particularly the groom, should they be allowed to have a talk on their own.

Out of the sample size of 250, 150 respondents voiced their dislike at the method of marriage negotiations. On a Likert scale (where 5 signified profound dislike and o signified no dislike/like), eighty respondents marked their answers within the 4-5 range. Fifty respondents chose 3-4 and the remaining ten respondents answered at 2 . Swarupa expressed indignation at the way the prospective brides have to appear before the groom's family, answer questions and the huge expenditure and preparations that preceded it.

\section{Figure 4 - Tabular Representation of Survey Results}

\begin{tabular}{|c|c|c|c|}
\hline \multirow[t]{2}{*}{ Category/Question } & \multicolumn{3}{|c|}{$\begin{array}{l}\text { Respondents [250] } \\
\text { Brahmins - 100; Kayasthas - 80; Baidyas - } 70\end{array}$} \\
\hline & Brahmins & Kayasthas & Baidyas \\
\hline In favour of arranged marriages & $\begin{array}{l}80 \\
{[80 \%]}\end{array}$ & $\begin{array}{l}50 \\
{[62 \%]}\end{array}$ & $\begin{array}{l}47 \\
{[67 \%]}\end{array}$ \\
\hline $\begin{array}{l}\text { Expressed dislike at the process of } \\
\text { negotiations }\end{array}$ & $\begin{array}{l}85 \\
{[85 \%]}\end{array}$ & $\begin{array}{l}49 \\
{[61 \%]}\end{array}$ & $\begin{array}{l}58 \\
{[82 \%]}\end{array}$ \\
\hline $\begin{array}{l}\text { Frustration and Despair as a result of } \\
\text { rejections }\end{array}$ & $\begin{array}{l}40 \\
{[40 \%]}\end{array}$ & $\begin{array}{l}47 \\
{[58 \%]}\end{array}$ & $\begin{array}{l}43 \\
{[61 \%]}\end{array}$ \\
\hline Refused to get married & $\begin{array}{l}10 \\
{[10 \%]}\end{array}$ & $\begin{array}{l}30 \\
{[37 \%]}\end{array}$ & $\begin{array}{l}25 \\
{[35 \%]}\end{array}$ \\
\hline $\begin{array}{l}\text { Felt humiliated and objectified during } \\
\text { negotiations }\end{array}$ & $\begin{array}{l}8 \mathrm{o} \\
{[8 \mathrm{o} \%]}\end{array}$ & $\begin{array}{l}50 \\
{[62 \%]}\end{array}$ & $\begin{array}{l}44 \\
{[62 \%]}\end{array}$ \\
\hline
\end{tabular}

Socialisation played an important role in adherence to arrange marriages. Respondents like Nivedita and Debangi observed that all their elder sisters had an arranged marriage. But, a significantly large number of respondents felt being objectified at the time of marriage negotiations. Although, largely in favour of arranged marriages, they disliked the way in which the girls were treated in the negotiations that preceded the marriage. Sudeshna, for example, felt that parental consent was necessary in a marriage but was outraged at the line of questioning adopted by the groom. The survey also revealed a considerable impact on the psychology of the prospective brides. Rejections drove some of them to despair and disillusionment. However, a disproportionately lower number of respondents' reply was negative to the question of their refusal to get married. This was 
primarily because the respondents felt the lack of alternatives in the absence of marriage. Respondents like Suhasini shuddered at the prospect of remaining unmarried. If unmarried, I will bring disgrace to my family. I do not have any choice. I am happy to marry a boy who likes me, observed Suhasini.

Poushali, on the contrary had found her husband quite easily. His family came to see me on a Wednesday. They liked me. Ankan (Poushali's husband) and me spoke aside in my room that day itself. We liked each other. I told Ankan that I shall continue with my job, but looking after the household will be my first priority. Ankan agreed and so did my in-laws. We got married in the following year, narrated Poushali. Poushali's insistence on the fact that her household will be her priority reflects the internalisation of patriarchal norms by a woman. While the girls are expected to manage her work and household, no reciprocal obligation rests on the boy. For Sanchita, the groom's family had expected dowry on the pretext that they were being too generous by accepting a dark-skinned girl as their daughter-in-law. Outraged at this, Sanchita called off the marriage. For respondents like Adrija, marriage was more an obligation and a compulsion. I did not marry because I love my husband. My parents decided the match and thus I got married. But I should love my husband. He is the father of my child, recounted Adrija. Consequently, the element of love relegated to the background. This was in tune with Hindu texts, which stated that the dharma (practice of religion) and praja (birth of an offspring to carry forward the line of patriarchal descent) become the primary objectives of marriage. Thus, marriage is viewed as an obligation that leads to a fuller and successful life and not necessarily a life in which there will be excitement and passion (Mullatti, 1995; Uberoi, 1993). Pleasure or kama, thus is the last component of marriage.

The survey revealed that educated brides often refused to succumb to such objectification. The higher the level of education, the lesser was the likelihood of their subjection to such degrading humiliation at the time of marriage negotiations. Respondents, like Rupsha, who have had a higher level of education often boldly stated that they had refused to give up their jobs. Respondents like Sutapa made it abundantly clear at the marriage negotiations that she would continue to look after her parents after her marriage. Being the only child, she would work to contribute a portion of her salary to her retired parents. Ipshita had walked into her drawing room to meet her prospective inlaws in a salwar kameez, much to the displeasure of her parents who wanted her to dress up in the traditional sari. My in-laws should see me the way I am. I do not want to disguise myself. If they accept me, they should like and accept me the way I am, said Ipsita.

What emerges from this analysis is the dominance of patriarchal injunctions in the marriage negotiations. The very first scene of a marriage negotiation involves a girl dressed up in a traditional attire, her head bent down, walking into the room to face her prospective-in laws in a shy, timid and docile manner. This stereotypical image of a bride is in fact so overarching that prospective brides are trained to behave in conformity. Soumita, like Gitanjali, recounted her experience of being trained in the acceptable ways of behaviour that are suited to the prospective bride. The profound patriarchal bias and consequent discrimination against women has been a cause of concern for prospective brides and their families. Family, as a disciplining institution enforces patriarchal values over prospective brides.

\section{Conclusion}

I hope I have a boy. The matrimonial market is too partial towards boys. At least, he will not have to face what I had been subjected to, observed Sanchayita. Sanchayita's parents had been able to get her married after five years of failed negotiations. This testimony is a crucial indicator of the social 
stigma assigned to the birth of a girl child. Education and awareness have improved the status of women in marriage negotiations. However, a significant number of women continue to be victimised by patriarchal norms. Being a woman, Sanchayita was desirous of a male offspring. She did not want her child to face the same subjugation that she herself had experienced. Thus, the heightened demand for a girl child and a skewed sex ratio, resulting from infanticide and foeticide stems from the structural aspects of patriarchy. Having experienced distress in her life, due to her gender affiliations, women yearned for a male child. Thus, the tripartite dimensions structural, functional and institutional patriarchy fuse to not leave a lasting impact to shape the views of the present and the future generations.

\section{References}

Alexander, M., Garda, L., Kanade, S., Jejeebhoy, S., \& Ganatra, B. (2006). 'Romance and sex - Premarital partnership formation among young women, and men, Pune district, India', Reproductive Health Matters, Volume 14 (28), pp. 144-155.

Batabyal, A. A. (2001). 'On the likelihood of finding the right partner in an arranged marriage', Journal of Socio-Economics, Volume 30 (3), pp. 273-28o.

Bowman, J.L. and Dollahite, D (2013). “Why Would Such a Person Dream About Heaven?”- Family, Faith, and Happiness in Arranged Marriages in India', Journal of Comparative Family Studies, Vol. 44 (2), pp. 207-225.

Chacko, E. (2003). 'Marriage, development, and the status of women in Kerala, India', Gender

and Development, Volume 11(2), pp.52-59.

Chandrasekhar, S. (1954). 'The family in India', Marriage and Family Living, Volume 16 (4), pp. 336- 342.

Chawla, D. (2007). 'I will speak out - Narratives of resistance in contemporary Indian women's

discourses in Hindu arranged marriages', Women and Language, Volume 30 (1), pp. 5-19.

Chowdhury, F. \& Travato, F. (1994). 'The role and status of women and the timing of marriage in five Asian countries', Journal of Comparative Family Studies, Volume 25 (2), pp. 143- 156.

Corwin, L. (1977). 'Caste, class and the love-marriage - Social change in India', Journal of Marriage and the Family, 39 (4), pp. 823-831.

Derne, S. (2005). 'The (limited) effect of cultural globalization in India-implications for culture theory', Poetics, Volume 33 (1), pp. 33-47.

De Silva, I. (2005). 'Family transition in South Asia - Provision of social services and social protection', AsiaPacific Population Journal, Volume 20 (2), pp. 13-46.

Doniger, W. \& Smith, B. (1991). The Laws of Manu, Harmondsworth, Penguin Classics.

Edathumparambil, B. (2017). Strangers to Spouses - A Study of the Relationship Quality in Arranged Marriages in India, Eugene, Wpif and Stock.

Feder, Ellen K. (1997). 'Disciplining the family—the case of gender identity disorder', Philosophical Studies, 85(2-3), pp. 195-211.

Feder, Ellen K. (2007). Family bonds_Genealogies of race and gender, New York, Oxford University Press.

Foucault, M. (1978/1976). The history of sexuality—an introduction, Vintage; originally published as La volonte' de savoir, Paris, Gallimard. 
Fuller, C. \& Narasimhan, H. (2008). 'Companionate marriage in India - the changing marriage system in a middle-class Brahman subcaste', Journal of the Royal Anthropological Institute, 14 (4), pp. 736- 754.

Ghimire, D., Axinn, W., Yabiku, S. \& Thornton, A. (2006). 'Social change, premarital nonfamily experience, and spouse choice in an arranged marriage society', American Journal of Sociology, Volume 111 (4), pp. $1181-1281$.

Grover, S. (2009). 'Lived experiences - Marriage, notions of love, and kinship support amongst poor women in Delhi', Indian Sociology, 43 (1), pp. 1- 33.

Jacobson, D. (1996). 'Social systems', In J. Heitzman and R. L. Worden (Eds.). India - A Country Study, Washington, Federal Research Division of the Library of Congress, pp. 231-294.

Jaiswal, T (2014). Indian Arranged Marriages - A Social Psychological Perspective, New York, Routledge.

Madathil, J. \& Benshoff, J. M. (2008). 'Importance of marital characteristics and marital Satisfaction - A comparison of Asian Indians in arranged marriages and Americans in marriages of choice', The Family Journal, Volume 16 (3), pp. 222-230.

Medora, N. P. (2003). 'Mate selection in contemporary India - Love marriages versus arranged marriages', In Hamon, R. R. and Ingolds, B. B. (Eds.), Mate selection across cultures, Washington DC., Sage Publications, pp. 209-230.

Medora, N. (2007). 'Strengths and challenges in the Indian family', Marriage and Family Review, Volume 41 (2), pp. 165- 194.

Myers, J. E., Madathil, J., \& Tingle, L. R. (2005). 'Marriage satisfaction and wellness in India and the United States - A preliminary comparison of arranged marriages and marriages of Choice', Journal of Counselling and Development, Volume 83 (2), pp. 183-19o.

Natrajan, R. \& Thomas, V. (2002). 'Need for family therapy services for middle-class families in India', Contemporary Family Therapy, Volume 24 (3), pp. 483-503.

Pasupathi, M. (2002). 'Arranged marriages - What's love got to do with it?' In M. Yalom \& L. Carstensen (Eds.). Inside the American couple - New thinking/new challenges, California, University of California Press, pp. 211-235.

Sandhya, S. (2009). 'The social context of marital happiness in urban Indian couples - Interplay of intimacy and conflict', Journal of Marital and Family Therapy, Volume 35 (1), pp. 74-96.

Sen, Simonti (2005). 'Gender and Politics', In Satyabrata Chakraborty (Eds.). Political Sociology, Delhi, Macmillan India Ltd, pp. 249-268.

Sen, S. (2020). 'Tradition-Technology Wedlock - The Paradoxical Modernisation of Matrimony', South Asian Survey, 27 (2), pp. 172-19o.

Singh, J. P. (2005). 'The contemporary Indian family' In B. N. Adams \& J. Trost (Eds.). Handbook of world families, California, Sage Publications, pp. 129-166.

Sonpar, S. (2005). 'Marriages in India- Clinical issues', Contemporary Family Therapy Volume 27 (3), pp. 301313.

Stopes-Roe, M. \& Cochrane, R. (1990). Citizens of this country - The Asian British, Clevedon, UK, Multilingual Matters Ltd.

Tuxen, N. (2013). 'Arranged love-conceptualising marriage on Shaadi.com', Reinvention-An International Journal of Undergraduate Research, BCUR/ICUR 2013 Special Issue, University of Warwick.

Yelsma, P. \& Athappilly, K. (1988). 'Marital satisfaction and communication practices - Comparisons among Indian and American couples', Journal of Comparative Family Studies, Volume 19 (1), pp. 37-54. 